\title{
Experimental Study on Flow Characteristics of Ice-Water Slurries in a Horizontal Pipe*
}

\author{
by Hiroshi TAKAHASHI ${ }^{1}$, Tadashi MASUYAMA ${ }^{2}$ \\ and Toshio KAWASHIMA ${ }^{3}$
}

\begin{abstract}
The pressure loss and the particle velocity profiles for ice-water slurry flows in a pipe were experimentally investigated. The pressure loss was larger than that for clear water flows at lower velocities. On the other hand, it was a little smaller than that for clear water flows at higher velocities. The particle velocity profile at lower velocities was distorted by the friction between the ice particle layer and the pipe wall. However, it approximately agreed with that of turbulent clear water flows at higher velocities.

A simplified model was proposed to examine the pressure loss for ice-water slurry flows in pipes at higher velocities. This model gave satisfactory results with experiments.
\end{abstract}

KEY WORDS: Ice-Water Slurries, Pressure Loss, Velocity Profile, Froude Number

\section{Introduction}

Liquid-solid flows are commonly encountered in several fields of industries, such as the chemical processing plant, the mining of coal and other ores ${ }^{1)}$ and the dredging. In the above operations, particles heavier than water such as sand, coal and iron ores have been mainly transported through pipelines. In particular, when coarse particles were transported to reduce the cost in crushing and dewatering, the motions of particles in water were dominated by the gravity force and drag force by fluid, and were little affected by the turbulence of the carrier water.

Ice-water slurry flows have recently received considerable attentions in order to utilize the ice particles as a coolant. For example, the applications of ice-water slurry flows to the air-cooling system ${ }^{2)}$, the heat storage plant ${ }^{3)}$ and the icebased heat pump ${ }^{4)}$ have been discussed.

In designing a hydraulic transport system through pipelines, it is very important to estimate the pressure loss for slurries, because some design parameters such as the transport velocity and the pump capacity are generally determined, based on the pressure loss. Much work therefore has been conducted on the pressure loss for slurries ${ }^{5) \sim 12)}$, and many empirical equations were proposed. However, as mentioned above, most of previous researchers dealt with the heavy particles (the specific gravity is larger than 1.0) to discuss the pressure loss. On the other hand, as the specific gravity of ice particles is smaller than that of water, the motions of particles are strongly affected by the turbulence of the carrier water, and are much different from those of heavy particles ${ }^{13)}$. This means that many previous empirical equations can not be

* Received November 1, 1991: accepted for publication January 29, 1992

1, 2. Faculty of Engineering, Tohoku University, Aoba-ku, Sendai 980, Japan

1. Res. Assoc., Dr.

2. Assoc. Prof., Dr.

3. Prof., Dr., Hachinohe Institute of Technology, Japan applied to such slurries.

Sellgren ${ }^{4)}$ presented five data on the pressure loss for ice-water slurry flows in his paper. However, these data are not enough to discuss the behavior of ice-water slurry flows in pipes, because the effect of solid concentrations on the pressure loss was not investigated. Furthermore, no work discussed the particle velocity profiles for ice-water slurry flows. That is, the behavior of ice-water slurry flows has not as yet been made clear.

The purpose of this study is therefore to experimentally investigate the pressure loss and the particle velocity profile for ice-water slurry flows in a horizontal pipe.

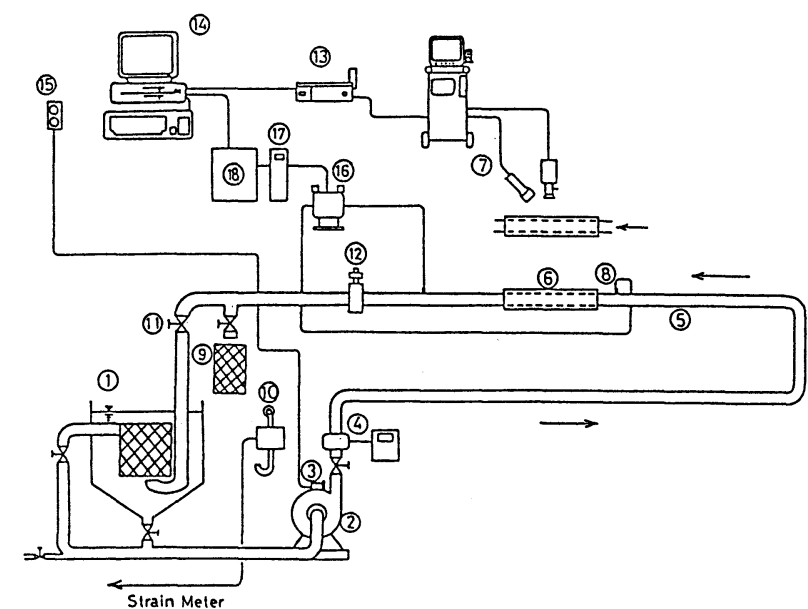

(10) Load Cell

(11) Directional Control Valve

(12) Pitot Tube

(13) $X-Y$ Coordinator

(14) Personal Computer

(15) Control Switch

(16) Differential Pressure Transducer

(17) Strain Meter

(18) A $/ D$ Converter

Fig. 1 Schematic diagram of experimental apparatus. 


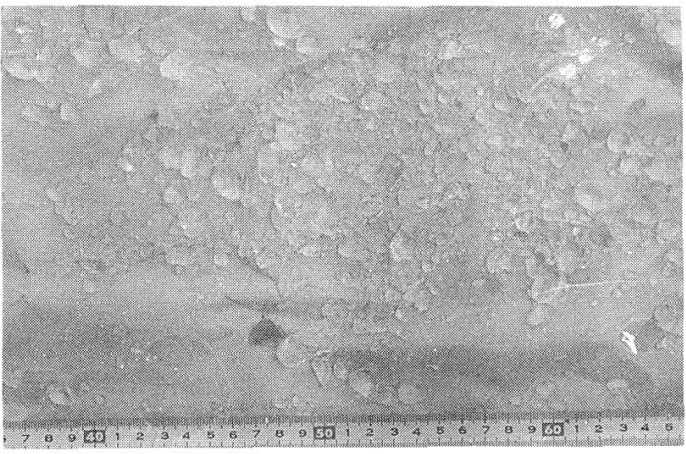

Fig. 2 Ice particles used in this study.

\section{Experimental Apparatus and Procedures}

The schematic diagram of experimental apparatus used in this study is shown in Fig. 1. As shown in this figure, it consists of a mixing tank, a solid pump, an electromagnetic flow meter, a test section, a water jacket and measuring devices of the delivered solid concentration. The test section is a $12 \mathrm{~m}$ long transparent acrylic pipe with $49.7 \mathrm{~mm}$ i.d. to allow visual observation of the particle behavior by a video camera. The test section is covered with a quadrilateral water jacket in order to eliminate the refraction of light by the curvature of the cylindrical transparent pipe.

The pressure loss was measured with a strain-gauge-type differential pressure transducer. The readings of it were transmitted through a strain meter and an $\mathrm{A} / \mathrm{D}$ converter to a personal computer (NEC PC-9801VM). The particle velocities were measured with a high speed video camera (NAC HSV-400) with a maximum of 400 fps. In this experiment, the shutter speed was set at $200 \mathrm{fps}(1 / 200 \mathrm{sec}$.), considering a maximum mean velocity of slurries in the pipe $(2.5 \mathrm{~m} / \mathrm{s})$. To assure easy visual observation of the behavior of particles, a small fraction $(\sim 3 \%)$ of ice particels were dyed red by using red dyestuff. The particle positions in a video image were determined with visual observation and were transformed into $\mathrm{x}$ and $\mathrm{y}$ co-ordinates with a $\mathrm{X}-\mathrm{Y}$ coordinator. These data were transmitted to the personal computer and stored on magnetic disks. The length by which particles moved in a short time of $\Delta t$ was obtained from $\mathrm{x}$ and $y$ co-ordinates, and then the particle velocities were calculated by dividing the length $\Delta L$ by $\Delta t$.

Fig. 2 shows the ice particles used in this experiment. The mean diameter of ice particels was obtained as follows: First, 50 particles were selected at random, and lengths of major and minor axes of individual particles were measured. Second, the volumes of individual particles were calculated by assuming ice particles as ellipsoids. Finally, the mean particle diameter was obtained as $d_{S}=12 \mathrm{~mm}$ by estimating the diameter of a sphere having the same volume as that of the ice particle. The specific gravity of ice particles was 0.917 . The maximum delivered concentration of ice particles obtained in this experiment was about $25 \%$. The delivered concentration of ice particles, $C_{v}$, is defined by

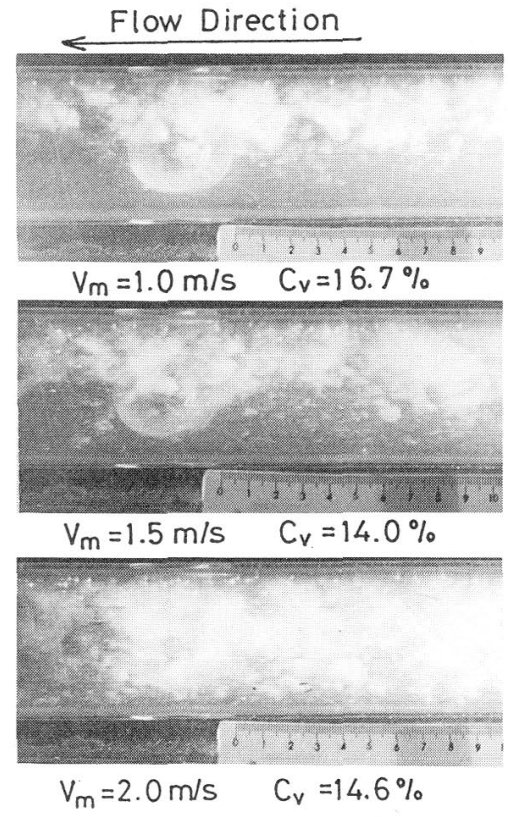

Fig. 3 Flow patterns of ice-water slurries.

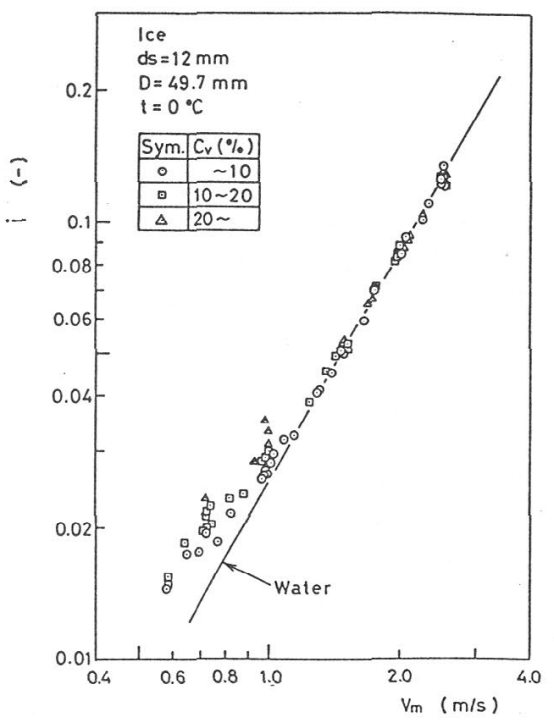

Fig. 4 Relationship between $i$ and $V_{m}$.

$$
C_{v}=\frac{Q_{s}}{Q_{s}+Q_{w}}=\frac{\left(G / \rho_{s}\right)}{A \cdot V_{m} \cdot T}
$$

Throughout this experiment, the temperature of the carrier water was kept at $0^{\circ} \mathrm{C}$ by pouring a mass of ice into the mixing tank. As ice particles are easily crushed during the transportation, so we renewed ice particles for each run of the measurement to avoid the change of the ice-particle sizes.

\section{Experimental Results}

(1) Pressure loss

Fig. 3 shows the behavior of ice particles flowing in the horizontal pipe. As ice particles float in the water, particles move in the upper region of the pipe at lower velocities. In this flow pattern, the friction between the ice particles and the pipe wall is important to discuss the pressure loss for 


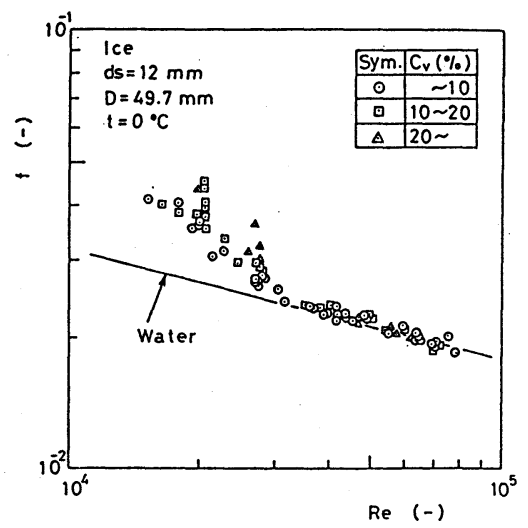

Fig. 5 Relationship between $f$ and $R e$.

slurries. Increasing the mean velocity of slurries in the pipe causes the dispersion of ice particles due to the increase of the turbulence of water flowing in the pipe. At higher velocities, ice particles dispersed uniformly over the cross section of the pipe.

Fig. 4 shows the relationship between the hydraulic gradients for ice-water slurry flows and the mean velocities. The hydraulic gradient is defined by

$$
i=\Delta P / \rho_{w} g L
$$

A solid line in this figure indicates the hydraulic gradients for water flows at $0^{\circ} \mathrm{C}$. At lower velocities $(<1 \mathrm{~m} / \mathrm{s})$, the hydraulic gradients for slurries are larger than those for water flows. This result is owing to the large frictional loss between the ice particles and the pipe wall. The hydraulic gradients for slurries are approximately equal or a little smaller than those for water flows at higher velocities $>1 \mathrm{~m} / \mathrm{s})$. The effects of delivered solid concentrations on the hydraulic gradients were not notable in the range of this experiment. However, at higher solid concentrations (Symbol $\odot$ ) and lower velocities, it was often observed that ice particles sticked each other and formed a mass of ice particles. The formation of the mass of ice particles was a typical feature for ice-water slurry flows. In such cases, as the mobility of this mass of ice particles was very low, the hydraulic gradients became large.

Fig. 5 shows the relationship between the friction coefficients for slurries and Reynolds numbers. The friction coefficients were obtained by using the Darcy-Weisbach's equation expressed by Eq.(3), and the experimental results of the pressure loss.

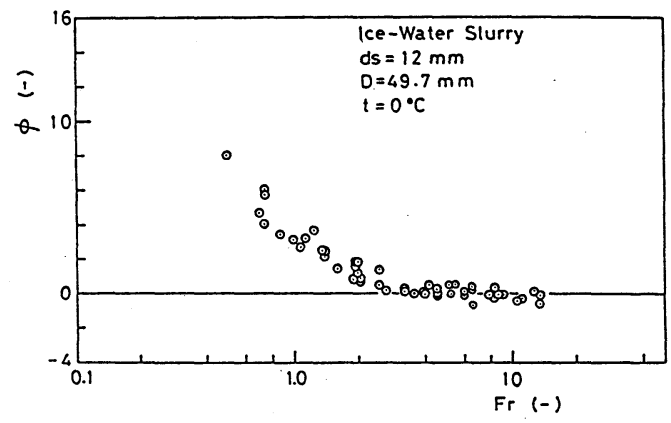

Fig. 6 Relationship between $\phi$ and $F r$.

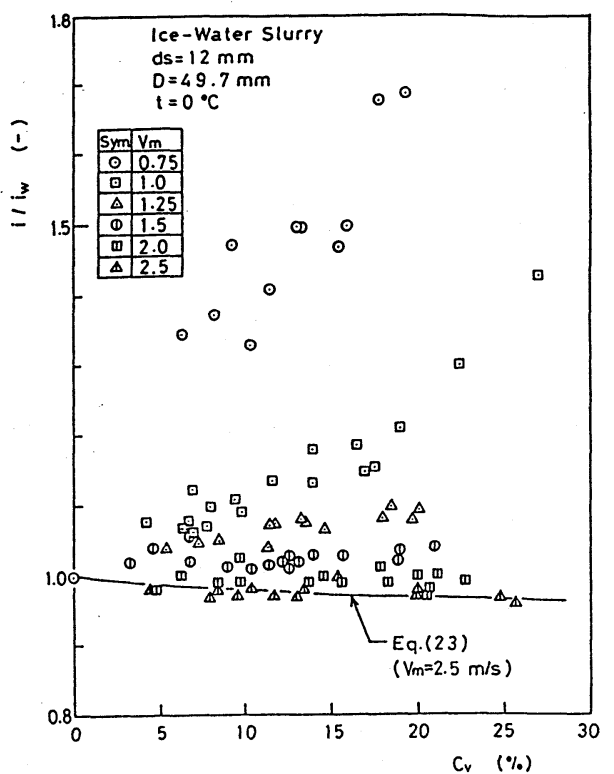

Fig. 7 Relationship between $i / i_{w}$ and $C_{\mathcal{V}}$.

$$
f=\frac{\Delta P}{L} \frac{2 D}{\rho_{m} \cdot V_{m}^{2}}
$$

A solid line in this figure indicates the Blasius's empirical equation for turbulent clear water flows in smooth pipes, expressed by

$$
f_{w}=0.3164 R e^{-0.25}
$$

where $f_{w}$ is the friction coefficient and $R e$ is the Reynolds number, defined by Eq.(5) according to Shook ${ }^{14)}$ and Shirakashi et al. ${ }^{15}$ )

$$
R e=V_{m} \cdot D / \nu
$$

The friction coefficients showed the same tendency as the hydraulic gradients.

Fig. 6 shows the relationship between the pressure loss coefficients and Froude number. They are defined as follows:

$$
\begin{aligned}
& \phi=\left(i-i_{w}\right) /\left(i_{w} \cdot C_{v}\right) \\
& F r=V_{m}{ }^{2} / g D \cdots \cdots \cdots
\end{aligned}
$$

The pressure loss coefficients decreased with an increase of $\mathrm{Fr}$, and showed negative values at higher Fr. This is owing to the change of the flow patterns from heterogeneous flow to homogeneous one according to the increase of Fr. The pressure loss coefficient for homogeneous slurries is expressed as follows ${ }^{16)}$ :

$$
\phi=S-1
$$

If the specific gravity of particles is smaller than unity, negative pressure loss coefficients are obtained. However, negative pressure loss coefficients have been also obtained for slurries of particles, whose the specific gravity was a little larger than unity ${ }^{15)}$. This means that the negative pressure loss coefficients at higher velocities can not be explained by only Eq.(8). That is, the mechanism on reducing the pressure loss for slurries of particles with densities close to that of 


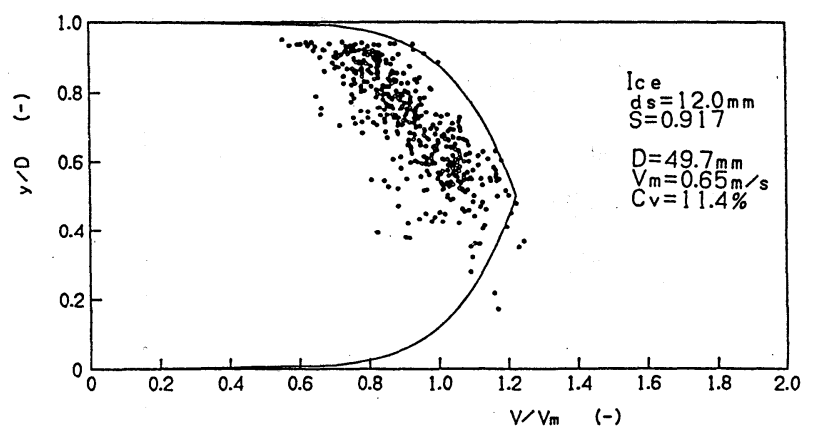

Fig. 8 Particle velocity profile.

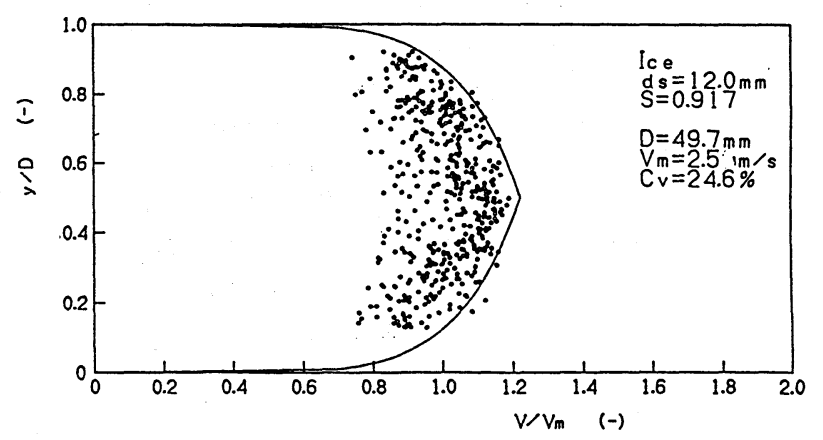

Fig. 9 Particle velocity profile.

water has not as yet been clarified.

Fig. 7 shows the relationship between the relative hydraulic gradients and the delivered solid concentrations. The solid line in this figure indicates the calculated results, which will be described later. The relative hydraulic gradients were obtained by dividing the hydraulic gradients for slurry flows by those for water flows at the same mean velocity. At lower velocities, the relative hydraulic gradients increased with increasing the solid concentrations. However, the rate of an increase of the relative hydraulic gradients with the solid concentrations decreased as the mean velocity of slurries increased. At higher velocities, the relative hydraulic gradients decreased with increasing the solid concentrations. As described earlier, the difference of these tendencies is owing to the change of flow patterns from heterogeneous flow (flow with a moving bed) to homogeneous one - i.e. the large values of relative hydraulic gradients at lower velocities are caused by the friction between the ice particle layer and the pipe wall.

\section{(2) Particle velocity profiles}

Figs. 8 and 9 show the particle velocity profiles at $V_{m}=$ $0.65 \mathrm{~m} / \mathrm{s}$ and $2.5 \mathrm{~m} / \mathrm{s}$, respectively. The solid lines in these figures indicate the velocity profiles of turbulent clear water flows, which are calculated from the $1 / 7$ th power law, given by

$$
V / V_{\max }=(y / R)^{1 / 7}
$$

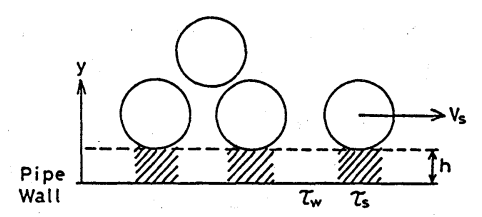

Fig. 10 Simplified model of ice-water slurry flows.
As mentioned earlier, the particle velocities were measured with X-Y coordinator. Therefore, three-dimensional pipe flow was measured two-dimensionally. This causes a considerable scatter of measured data as shown in these figures. However, it was confirmed that at lower velocities, the particle velocity profile shown in Fig. 8 was distorted by the particle layer formed at the top of the pipe wall in comparison with the fluid velocity profile for turbulent clear water flows (solid line). As the carrier water did not have enough turbulent intensity to disperse the ice particles over the cross section of the pipe, ice particles did not disperse in the lower region of the pipe. As a result, little data on the particle velocities were obtained within the range of $y / D<0.5$. The relative velocity between the water and ice particles was considered to be negligibly small because the specific gravity of ice particles was close to that of water and particles well followed the fluid motion. Therefore, the fluid velocity for slurry flows in the upper region of the pipe was considered to be smaller than that of turbulent clear water flows. According to the above considerations, the fluid velocity for slurry flows in the lower region of the pipe was inferred to be larger than that of turbulent clear water flows.

On the other hand, the turbulent intensity of the carrier water increased as increasing the mean velocity of slurries, causing the dispersion of ice particles over the cross section of the pipe. As shown in Fig. 9, ice particles dispersed uniformly over the cross section of the pipe at higher velocities, and particle velocities were approximately equal to those for turbulent clear water flows. However, these results described here were obtained in the range of $C_{v}<25 \%$. Therefore, more investigations on the effects of ice particle concentrations over $25 \%$ are still needed.

\section{A Consideration on Reducing the Pressure Loss}

Fig. 10 shows the simplified model of slurry flows at higher velocities. In this figure, $V_{s}$ shows the particle velocity, and $h$ shows the distance between the pipe wall and the first particle layer. It is of course a fact that particles move randomly in the pipe, and collide with the pipe wall even though the mean velocities are high enough. But, it is not proper to consider the frequent collisions between particles and the pipe wall at higher velocities from the following reason. If the frequent collisions occur, the hydraulic gradients for slurries are larger than those for turbulent clear water flows because of the frictional loss at the collisions. However, the experiments show approximately the same hydraulic gradients between them. Therefore, it can be considered that the thin fluid membrane exists between the pipe wall and the first particle layer. As particles move randomly, the value of $h$ fluctuates during the transportation. In this study, the value of $h$ is assumed to be the time-averaged one. After Shook ${ }^{14)}$, the total wall shear stress can be assumed as follows:

$\tau=(1-\alpha) \tau_{w}+\alpha \tau_{s}$

where $\tau$ is the total wall shear stress, $\tau_{w}$ is the shear stress between the fluid and the pipe wall, $\tau_{s}$ is the shear stress which 


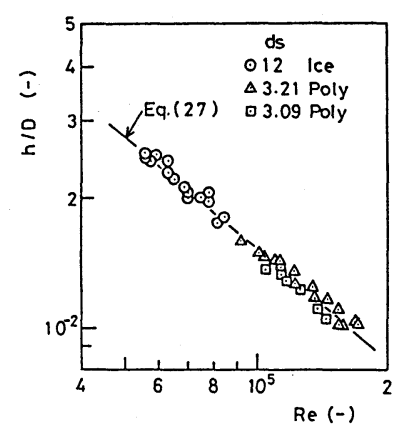

Fig. 11 Relationship between $h / D$ and $R e$.

is effected by the motion of the nearest particles, and $\alpha$ is the fraction of the pipe wall for which the local shear stress is effected by the motion of the nearest particles. As $h$ is very small, the fluid between the pipe wall and the first particle layer can be considered to be the lubricating layer ${ }^{14)}$. In this case, Navie-Stokes equations and boundary conditions are given as follows ${ }^{17)}$ :

$$
\begin{aligned}
& \frac{\partial P}{\partial x}=\mu \frac{\partial^{2} u}{\partial y^{2}} \\
& y=0 ; u=0, y=h ; u=V_{S}
\end{aligned}
$$

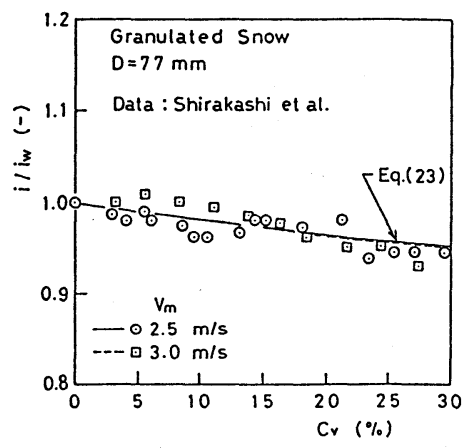

Fig. 12 Comparison of calculated results with experimental ones for $i / i_{w}$.

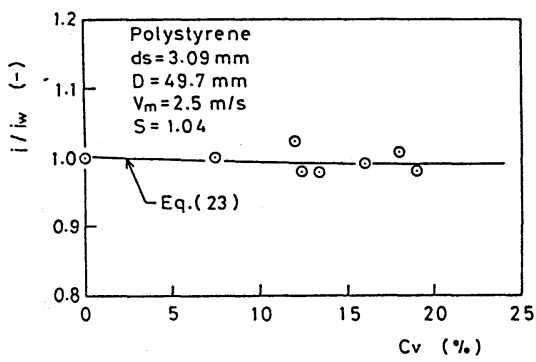

Fig. 13 Comparison of calculated results with experimental ones for $i / i_{w}$.

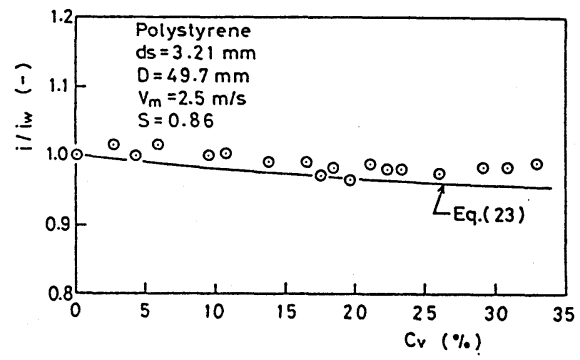

Fig. 14 Comparison of calculated results with experimental ones for $i / i_{w}$.
Integrating Eq.(11) derives the following expression for the fluid velocity profile.

$$
\begin{aligned}
u & =\frac{V_{s}}{h} y\left\{1+\frac{h^{2}}{2 \mu V_{s}}\left(-\frac{\partial P}{\partial x}\right)\left(1-\frac{y}{h}\right)\right\} \\
& =\frac{V_{s}}{h} y\left\{1+\frac{h^{2}}{2 \mu V_{s}}\left(\frac{\Delta P^{\prime}}{L}\right)\left(1-\frac{y}{h}\right)\right\} \cdots \cdots
\end{aligned}
$$

where $\Delta P^{\prime} / L$ is the pressure loss caused by $\tau_{s}$.

The shear stress $\tau_{s}$ is expressed as follows in terms of the eddy viscosity, $\varepsilon$ :

$$
\tau_{s}=\rho \nu\left(1+\frac{\varepsilon}{\nu}\right)\left(\frac{d u}{d y}\right)_{y=0}
$$

By using Eq.(14), then Eq.(15) is rewritten as follows:

$$
\tau_{s}=\mu K \frac{V_{s}}{h}+\frac{h}{2} K \frac{\Delta P^{\prime}}{L} .
$$

where $K=1+\varepsilon / \nu$

Considering that the effect of particle concentrations on shear stress is very important, in this study, the relationship between the shear stress, $\tau_{s}$ and the pressure loss, $\Delta P^{\prime} / L$ was assumed as follows:

$$
\Delta P^{\prime} / L=C_{v}\left(4 \tau_{s} / D\right)
$$

By substituting Eqs.(16) and (18) into Eq.(10), the next equation is obtained.

$$
\tau=(1-\alpha) \tau_{w}+\frac{\alpha \cdot \mu K\left(V_{s} / h\right)}{\left(1-2 C_{v} K h / D\right)} .
$$

Eq.(19) is rewritten as follows in terms of the friction coefficients.

$$
f=(1-\alpha) f_{w}+\frac{\alpha \cdot 8 K\left(V_{s} / V_{m}\right)}{\left[1-2 C_{v} K(h / D)\right] \operatorname{Re}(h / D)}
$$

As shown in Fig. 9, the velocities of the particles approximately coincide with those of the fluid. Therefore, the next equation is obtained.

$$
V_{s} / V_{m}=1.3(h / D)^{1 / 7}
$$

After Shook, $\alpha$ is assumed to be approximately equal to $C_{\nu}$, then Eq.(20) is expressed as follows:

$$
f=\left(1-C_{v}\right) f_{w}+\frac{10 C_{v} K(h / D)^{1 / 7}}{\left[1-2 C_{v} K(h / D)\right] \operatorname{Re}(h / D)}
$$

Then, we finally obtain the following expression for the relative hydraulic gradients:

$$
\begin{aligned}
& \frac{i}{i_{w}}=\frac{f \rho_{m}}{f_{w} \rho_{w}}=\left\{\left(1-C_{v}\right)+\frac{10 C_{v} K(h / D)^{1 / 7}}{\left[1-2 C_{v} K(h / D)\right] R e(h / D) f_{w}}\right\} \\
& \cdot\left[\left(1-C_{v}\right)+C_{v} \cdot S\right]
\end{aligned}
$$

Particles with densities close to that of water well follow the fluid motion because the slip velocity. which is defined by the difference between the fluid and particle velocity is negligibly small. Therefore, it is reasonable to assume that at higher velocities, particles disperse uniformly over the cross section of the pipe by the turbulence of the fluid, and particles exist in the region of the turbulent core. In this case, $h / D$ is approximated as follows:

$$
h / D=\left(\delta_{1}+\delta_{b}\right) / D
$$

where $\delta_{1}$ and $\delta_{b}$ are thickness of the viscous sublayer and the buffer layer, respectively, and are given by

$$
\delta_{1}=5 v / u_{*}, \delta_{b}=70 v / u_{*}
$$

where $u_{*}$ is the frictional velocity, and is obtained by 
$u_{*}=\sqrt{D \cdot i \cdot g / 4}$

Fig. 11 shows the relationship between $h / D$ and Re. $h / D$ was calculated from Eq.(24) by using the experimental results of the hydraulic gradients. It can be seen that all data fell close to an unique line independent of the particles. A solid line in this figure indicates the empirical equation obtained by the least square fittings, given by

$$
h / D=315 \cdot R e^{-0.86}
$$

In order to calculate the relative hydraulic gradients, it is needed to obtain the value of $K$. The authors found by trial and error that $K=4.5$ gave satisfactory results. The solid line in Fig. 7 shows the results calculated from Eq.(23). Figs. 12 $\sim 14$ show the comparison of the calculated results with the experimental ones for several particles. As shown in these figures, the agreement is satisfactory, hence this model proposed in this study can be considered to be reasonable. However, as mentioned above, this model needs the empirical coefficient, $K$. So, this model is applied in the range of this experiment $\left(d_{s}<12 \mathrm{~mm}, 0.8<S<1.04, V_{m}>2.0 \mathrm{~m} / \mathrm{s}\right)$.

\section{Conclusions}

The pressure loss and the particle velocity profiles for ice-water slurry flows were experimentally investigated. The conclusions obtained in this study are summarized as follows:

(1) At lower velocities, ice particles moved in the upper region of the pipe. In this flow pattern, the friction between the ice particles and the pipe wall was large. Hence, the pressure loss for ice-water slurry flows was larger than those for turbulent clear water flows. The particle velocity profiles were distorted in comparison with the fluid velocity profile for turbulent clear water flows. The particle velocities were smaller than those of turbulent clear water flows in the range of $y / D>0.5$.

(2) At higher velocities, ice particles dispersed uniformly over the cross section of the pipe. In this flow pattern, slurry flows were considered to be homogeneous, and the pressure loss was approximately equal or a little smaller than that for turbulent clear water flows. Furthermore, the particle velocity profiles approximately coincided with those for turbulent clear water flows.

(3) The simplified model for slurry flows was proposed in order to investigate the reduction of the pressure loss at higher velocities. This model gave the satisfactory results with the experiments for the pressure loss, hence this model was confirmed to be reasonable.

\section{Nomenclature}

$A \quad$ : cross sectional area of the pipe

$C_{v} \quad$ : delivered solid concentration by volume

$D \quad$ : internal pipe diameter

$[-]$

[m ]

$\mathrm{Fr} \quad$ : Froude number defined by Eq.(7)

$f \quad$ : friction coefficient

$[-]$

$f_{w} \quad$ : friction coefficient for the smooth pipe
$G \quad:$ mass of the sampled ice particles

[ $\mathrm{kg}$ ]

$g \quad$ : gravitational acceleration

$\left[\mathrm{m} / \mathrm{s}^{2}\right]$

$h \quad:$ distance between the pipe wall and the first particle layer

[m ]

$i \quad$ : hydraulic gradients for slurries

$i_{w} \quad$ : hydraulic gradients for clear water flows

$L \quad$ : length of the measuring section

$\Delta P \quad$ : pressure loss

[ $\mathrm{Pa}$ ]

$Q_{s} \quad$ : delivered volume of ice particles per unit time $\left[\mathrm{m}^{3} / \mathrm{s}\right]$

$Q_{w}:$ delivered volume of water per unit time $\quad\left[\mathrm{m}^{3} / \mathrm{s}\right]$

$R \quad$ : pipe radius

$R e \quad$ : Reynolds number defined by Eq.(5)

[ $\mathrm{m}$ ]

$S \quad$ : specific gravity

$[-]$

$T \quad$ : sampling time

$V \quad$ : local fluid velocity

$[-]$

$[\mathrm{s}]$

$[\mathrm{m} / \mathrm{s}]$

$[\mathrm{m} / \mathrm{s}]$

$\begin{array}{ll}V_{\max }: \text { maximum fluid velocity in the pipe } & {[\mathrm{m} / \mathrm{s}]} \\ V_{s}: \text { local particle velocity } & {[\mathrm{m} / \mathrm{s}]}\end{array}$

$V_{S} \quad$ : local particle velocity

[m ]

$\alpha \quad:$ fraction of the pipe wall for which the local shear stress is effected by the motion of the nearest particles

$\varepsilon \quad$ : eddy viscosity

$\mu \quad$ : viscosity of water

$\nu \quad$ : kinematic viscosity of water

$\left[\mathrm{m}^{2} / \mathrm{s}\right]$

$\rho_{m} \quad$ : density of ice-water slurry

$\left[\mathrm{kg} / \mathrm{m}^{3}\right]$

$\tau \quad:$ total wall shear stress

[ $\mathrm{Pa}$ ]

$\tau_{S} \quad:$ shear stress which is effected by the motion of the nearest particles

$\tau_{w} \quad:$ shear stress between the fluid and the pipe wall $\quad[\mathrm{Pa}]$

$\phi \quad$ : pressure loss coefficient defined by Eq.(6) [ ] ]

\section{References}

1) Duckworth, R.A. et al.: J. of Pipelines, Vol. 3, No. 1, pp. $251 \sim$ 265, (1983)

2) Umemura, T.: Reitou, Vol. 58, No. 673,pp. $1085 \sim 1093,(1983)$ (In Japanese)

3) Okada, T. et al.: Kenchikusetsubi to Haikangijyutsu,Vol. 26, No. 11 , pp. $127 \sim 130$, (1988) (In Japanese)

4) Sellgren, A.: Proc. of the 10th Int. Conf. on the Hydraul. Transport of Solids in Pipes, Paper F3, (1986)

5) Durand, R.: Proc. of Int. Assoc. of Hydraul. Research, Minneapolis, pp. $89 \sim 103,(1953)$

6) Newitt, D.M. et al.: Trans. Instn. Chem. Engrs., Vol. 33, pp. 93 $\sim 113,(1955)$

7) Condolios, E. et al.: Chem. Engng., Vol. 8, pp. $131 \sim 138,(1963)$

8) Zandi, I. et al.: J. of the Hydraul. Div., Proc. of ASCE. Vol. 93, No. HY3, pp. $145 \sim 159$, (1967)

9) Televantos, Y. et al.: Can. J. Chem. Engng., Vol. 57, pp. $255 \sim$ 262, (1979)

10) Maruyama, T. et al.: J. of Chem. Engng. of Japan, Vol. 13, No. 4, pp. $269 \sim 274,(1980)$

11) Shook, C.A.: J. of Pipelines, Vol. 1, No. 1, pp. $83 \sim 92,(1981)$

12) Noda, K. et al.: Proc. of the 9 th Int. Conf. on the Hydraul. Transport of Solids in Pipes, Paper D4, (1984)

13) Sumer, B.M. et al.: J. Fluid Mech., Vol. 109, pp. $311 \sim 337$, (1981)

14) Shook, C.A.: Can. J. Chem. Engng, Vol. 63, pp. $861 \sim 869$, (1985)

15) Shirakashi, M. et al.: J. of the Japanese Soc. of Snow and Ice, Vol. 45, No. 1, pp. $33 \sim 39$, (1983) (In Japanese)

16) Babcock, H.A.: Proc. of the 1st Int. Conf. on the Hydraul. Transport of Solids in Pipes, Paper H1, (1970)

17) Okamoto, J. et al.: Tribology nyumon, Saiwai shobo, pp. $87 \sim 97$, (1990) 


\section{水平管内水水スラリーの流動特性に関する実験的研究}

高橋 弘 $^{1}$ 益山 忠 $^{2}$ 川島倰夫 ${ }^{3}$

水平管内における水水スラリーの王力損失および粒子の速度分 布について, 主として実験的に検討した。低流速域ではスラリー の王力損失は清水の王力損失よりも大きくなること, および粒子 の速度分布は清水流の乱流速度分布と比較して歪められることが 分かった。高流速になると王力損失の低減が見られること，およ び速度分布は清水流のそれとほぼ等しくなることが確かめられた。 また簡単なモデルを提案し, 高流速域における王力損失の低減に
ついて考察を行った。本研究で提案したモデルによる計算値と実 験值とはほぼ一致することが確かめられた。

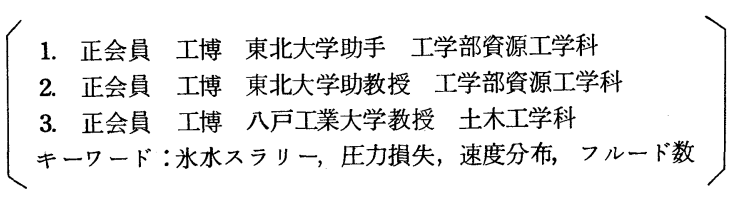

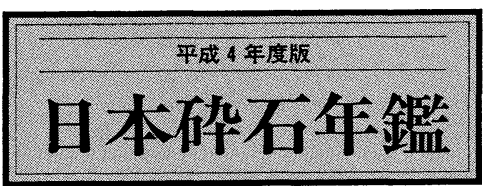

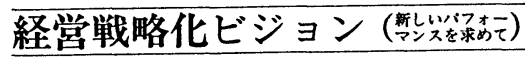
砕石業の新なな社会的役割、使命、さらには将来のあ るへき姿、現在の状況から将来に向けての各企業、地 域組織、そして業界全体の果たすへき可能な努力の方 向を求め、道案内、指針としている。

\section{全国都道府県の砕石業展望}

本紙記者が直接全国都道府県を取材し、行政施策、砕 石業の実態をまとめたもので、とくに認可業者一覧表 は、砕石業者の住所、電話番号、代表者氏名、採取地、 認可数量、岩質など、その内容が一目で分かるわが国 唯一の貴重な資料。

砕石製造業わよび岩石採取場の概要 昭和62年から平成 2 年までの企業形態、资本金別法人 数、生産規模別採取場数の推移を通商産業省の資料に より集計した。

\section{砕石生産状況}

昭和 62 年から平成 2 年までの岩石別生産量、製品別生 産量を通商産業省資料により集計した。

石灰砕石の生産推移 石灰石からの砕石生産状況を通商産業省資料により集 計した。
日本砕石協会 推萀

日本砕石新聞社 発刊

A 4 判 400 頁

定 価 20,600 円(税込)

\section{通商産業省砕石統計年報}

昭和62年から平成 2 年までの採石法に定められた岩 石、および鉱業法に定められた鉱物のうち石灰石、け い石、ドロマイトを砕石としているもので、通商産業 局別、都道府県別の事業所数、用途・品種別の生産、 ならびに用途別、出荷先都道府県別の出荷量を通商産 業省資料によりまとめた。

破砕・選別機械、重機類の設備状況 昭和62年から平成 2 年度までの採掘機械、使用火薬、 破砕・選別設備、積込・運般機械の保有状況を通商産 業省資料により集計した。

採石災害の発生状況および防止施設 昭和62年から平成 2 年までの災害発生状況、災害防止 施設を通商産業省資料によりまとめた。

砂利採取業の概要（平成 2 年度）

砂利採取の地建別、採取地別の採取場数、採取量なら ひに機械設備設置状況、砂利の販売先別販壳数量、購 入者別睡入数量を通商産業省、建設省の資料によりま とめた。

\section{採石関連各種手数料の一覧表}

政府は各種手数料の改正を公布し、平成 3 年 4 月 1 日 から実施した。この中から採石業に関係のある採石法、

\section{日本砕石新聞社}

干 101 東京都千代田区内神田 2-4-2 山崎ビル

電話 03-3256-1739 FAX03-3258-0528 砂利採取法、鉱業法、ならびに火薬類取締法の改正手 数料を揭載。

砕石工場における法定管理者等の一覧表 採石業務管理者、採石のための掘削作業主任者など法 定管理者の職務内容ならひに資格、对象工場を詳述。

品質管理技術者の関係 J I S 規格一覧表 コンクリート用砕石・砕砂の J I S、ならびに骨材の 各試験方法、路盤材料のC B R 試験方法、レデーミク ストコンクリート用骨材の规格、標準方るい、数值の 丸め方なと、品質管理技術者に必要な関係 J I S 規格 を集録した。

\section{採石技術指導基準書}

採石業の実施に際し、一般的に採用すべき災害防止方 法を説明し、採石業者の自主的な災害防止措置の指針 とするとともに、都道府県知事か採石法の規定に基つ いて行う採取計画の認否の処分についての審查基準を 目的としている。

\section{採石用語の基礎知識}

砕石業にたずさわる事業者、管理者、監督者、作業者 のために、切羽から建設機械、破砕・選別、災害防止 関係に至るまで、実務に必要な広範囲の用語を 700 語以 上に集大成した生きた砕石用語事典で、半恒久的な内 容とした。 